\title{
Intestinal protozoa in hospitalized under- five children with diarrhoea in Nampula - a cross-sectional analysis in a low-income setting in northern Mozambique
}

\author{
Adilson Fernando Loforte Bauhofer ${ }^{1,2^{*}}$ (D), Idalécia Laurinda Carlos Cossa-Moiane ${ }^{1,3}$, \\ Selma Domingos Amadeu Marques ${ }^{4}$, Esperança Lourenço Alberto Mabandane Guimarães ${ }^{1,2}$, \\ Benilde António Munlela ${ }^{1,4}$, Elda Muianga Anapakala ${ }^{1}$, Jorfélia José Chiláule ${ }^{1}$, Marta Cassocera ${ }^{1,2}$, \\ Jerónimo Souzinho Langa', Assucênio Chissaque ${ }^{1,2}$, Júlia Assiat Monteiro Sambo 1,2, \\ Lena Vânia Manhique-Coutinho', Diocreciano Matias Bero', Timothy Allen Kellogg ${ }^{5}$, \\ Luzia Augusta Pires Gonçalves ${ }^{6}$ and Nilsa de Deus ${ }^{1,7}$ (iD
}

\begin{abstract}
Background: In Mozambique, infection by intestinal parasites is reported all over the country. However, infection in children with diarrhoea is mostly focused in the southern region of Mozambique. This work aims to determine the frequency and potential risk factors for infection by Cryptosporidium spp., Giardia lamblia, and Entamoeba histolytica in children under-five years hospitalized with diarrhoea in Hospital Central de Nampula, northern Mozambique.

Methods: A cross-sectional hospital-based surveillance was conducted between March 2015 and January 2018 in children admitted with diarrhoea in Hospital Central de Nampula. Sociodemographic information was obtained through semi-structured interviews applied to the children's caregivers. A single stool sample was collected from each child to detect antigens from Cryptosporidium spp., G. lamblia, and E. histolytica using an immune-enzymatic technique. Crude and adjusted odds ratios (with 95\% Confidence Intervals) were obtained by logistic regression models to identify factors associated with infection by Cryptosporidium spp. and G. lamblia.
\end{abstract}

Results: The median age and interquartile intervals of our sample population was 12 months (8-20). Intestinal protozoa were detected in $21.4 \%$ (59/276). Cryptosporidium spp. was the most common protozoa $(13.9 \%-38 / 274)$, followed by G. lamblia ( $9.1 \%$ - 25/274) and E. histolytica (0.4\% - 1/275). Children with illiterate caregiver's ( $p$-value = 0.042 ) and undernourished ( $p$-value $=0.011$ ) were more likely to be infected by Cryptosporidium spp. G. lamblia was more common in children living in households with more than four members ( $p$-value $=0.039$ ). E. histolytica was detected in an eleven month's child, co-infected with Cryptosporidium spp. and undernourished.

(Continued on next page)

\footnotetext{
* Correspondence: adilsonbauhofer@gmail.com

${ }^{1}$ Instituto Nacional de Saúde (INS), Maputo, Mozambique

${ }^{2}$ Instituto de Higiene e Medicina Tropical, Universidade Nova de Lisboa, Lisboa, Portugal

Full list of author information is available at the end of the article
}

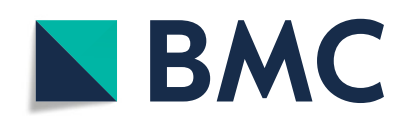

(c) The Author(s). 2021 Open Access This article is licensed under a Creative Commons Attribution 4.0 International License, which permits use, sharing, adaptation, distribution and reproduction in any medium or format, as long as you give appropriate credit to the original author(s) and the source, provide a link to the Creative Commons licence, and indicate if changes were made. The images or other third party material in this article are included in the article's Creative Commons licence, unless indicated otherwise in a credit line to the material. If material is not included in the article's Creative Commons licence and your intended use is not permitted by statutory regulation or exceeds the permitted use, you will need to obtain permission directly from the copyright holder. To view a copy of this licence, visit http://creativecommons.org/licenses/by/4.0/. The Creative Commons Public Domain Dedication waiver (http://creativecommons.org/publicdomain/zero/1.0/) applies to the data made available in this article, unless otherwise stated in a credit line to the data. 


\begin{abstract}
(Continued from previous page)
Conclusion: Cryptosporidium spp. and Giardia lamblia were the most common pathogenic intestinal protozoa detected in children with diarrhoea hospitalized in the Hospital Central de Nampula. Our findings obtained highlight the importance of exploring the caregiver's education level, children's nutritional status for infections with Cryptosporidium spp., and living conditions, namely crowded households for infections with G. lamblia in children younger than five years.
\end{abstract}

Keywords: Diarrhoea, Children, Intestinal Protozoa, Related factors, Low-income setting, Nampula province, Mozambique

\section{Background}

Diarrhoea is the second leading cause of death in children under five years [1]. Diarrhoea can be caused by bacteria, viruses, and parasites [2-4]. Among parasites, the intestinal protozoa Cryptosporidium spp. is the most attributable to moderate-to-severe diarrhoea in children younger than five in sub-Saharan Africa and Asia [3]. The second and third most common intestinal protozoa identified in children with diarrhoea are Giardia lamblia and Entamoeba histolytica, respectively [5-7].

Transmission of intestinal protozoa occurs by the ingestion of contaminated food and water or by direct contact with infected individuals or animals $[8,9]$. Host and environmental characteristics such as age, nutritional status, access to treated water, animal contact, and, population density are important factors in the occurrence of parasites infections [10-14].

Mozambique is a low-income country, with reports of intestinal parasites infections in children with diarrhoea, mostly in the southern region, having identified a frequency of $16.1 \%$ in Maputo city and $14.4 \%$ in Manhiça district, using microscopic diagnostic techniques $[3,7$, 15, 16]. Using a more sensitive technique, the EnzymeLinked Immunosorbent Assay (ELISA), a second study also in the Manhiça district reported the frequency of Cryptosporidium spp., G. lamblia, and E. histolytica/dispar in children with diarrhoea by 18.7, 17.2, and 10.2\%, respectively [7].

A national survey in school-age children identified Nampula - a northern province of Mozambique - as one of the most affected by parasites infections [17]. A second study conducted in Hospital Central de Nampula (HCN) observed G. lamblia as the most common parasite, followed by Cryptosporidium spp. in a pooled estimation in children younger than five years with either diarrhoea, malnutrition, or Human Immunodeficiency Virus (HIV) [18]. However, parasites infections in children with only diarrhoea are not reported, neither risk factors for this group [18].

A pooled analysis of a surveillance system in four provinces of Mozambique indicated Nampula province as the one with the highest risk of infection for
Cryptosporidium spp. in children younger than 15 years [5]. Nampula province has poor health indicators, with recurrent reports of cholera outbreaks [19]. The previous results from the surveillance system (Vigilância Nacional de Diarreias - ViNaDia or National Surveillance of Diarrhoea) failed to indicate risk factors for protozoans in each province [5]. Therefore, this analysis aims to determine the frequency of intestinal protozoa infections and associated risk factors in children younger than five years admitted with diarrhoea in Hospital Central de Nampula, in the Northern region of Mozambique.

\section{Methods}

\section{Study design, site, population}

Hospital-based, cross-sectional surveillance (ViNaDia) was conducted from March 2015 to January 2018 in Hospital Central de Nampula (HCN), Nampula province, located in a low-income area of the North region of Mozambique. This hospital was selected for the following reasons: $\mathrm{HCN}$ is the provincial and regional referrall hospital, has an inpatient paediatric service, and a reliable system for collection, storage, and transportation of stool samples to Instituto Nacional de Saúde (INS) - Mozambique.

Children aged 0-59 months hospitalized in the $\mathrm{HCN}$ paediatric services with diarrhoea, defined as the passage of three or more loose or liquid stools in $24 \mathrm{~h}$ were included [20], children who could provide a stool sample and those whose caregivers consented their participation in the ViNaDia were eligible to participate. Children with nosocomial diarrhoea were ineligible to participate in the ViNaDia.

Children overweight $(+2<\mathrm{z} \leq+5)$ or with outlier Zscores values were excluded from the nutritional status analysis [21].

\section{Sample size calculation}

OpenEpi [22] was used to calculate the minimum sample size necessary to estimate the prevalence of parasites with $95 \%$ confidence interval (CI), design effect 1 , desired precision of $5.0 \%$, and an estimated frequency of $18.7 \%$ for Cryptosporidium spp., $17.2 \%$ for Giardia 
lamblia, and $10.2 \%$ for Entamoeba histolytica from a previous study conducted in Mozambique in children aged 0-59 months with diarrhoea [7]. Based on the first estimate (18.7\%) that provides the higher value of the sample size and a $10 \%$ non-response expected rate, the sample size was 258 children.

\section{Variables of analysis and anthropometric measurements}

Sociodemographic and epidemiological data were previously obtained at the health facility using semistructured interviews with the children's caregivers. Some of the variables included information such as sex, age, history of animal contact defined as having close contact with an animal or their excrements in areas where the child circulated. Children's weight was obtained in the clinical records or by scaling. For children under two years, weight was measured while the child was lying down, while the weight for children aged two years or older were measured standing. The anthropometric indicator, weight-for-age Z-score (WAZ) was calculated to identify underweight status using WHO software Anthro version 3.2.2 for children younger than five years. Nutritional status was classified as well-nourished $(-2 \leq \mathrm{z} \leq+2)$ and undernourished $(-6 \leq \mathrm{z}<-2)$ [21].

\section{Sample collection and handling}

A single stool sample from each child was collected in a polyester flask and stored in $-20^{\circ} \mathrm{C}$ until shipment to the Laboratory of Parasitology (national reference laboratory) of INS in Maputo (capital of Mozambique) for laboratory diagnosis. Sample shipment to Maputo was made once a week during the recruitment period.

\section{Laboratory diagnosis}

Intestinal protozoa diagnosis was performed using an individual Enzyme-Linked Immunosorbent Assay (ELISA) (TechLab, Inc., Blacksburg, VA, USA) according to manufacturer recommendations to detect antigens of Cryptosporidium spp. oocysts, G. lamblia cysts, and E. histolytica cysts from stool samples. The sensitivity of the kits range from 97 to $100 \%$, and the specificity range from 95 to $100 \%$ [23-25].

\section{Data management and statistical analysis}

To minimize entry errors, survey data were entered twice into a database using Epi Info ${ }^{\text {тм }}$ 3.5.1 (Centers for Disease Control and Prevention, Atlanta, 2008) followed by data comparison and inconsistencies resolution if necessary.

IBM SPSS software (International Business Machines Corporation Statistical Package for the Social Science, Armok, NY: IBM Corp, 2011, version 26.0) was used to analyse data. Descriptive statistics were used to describe sample characteristics. Proportions and corresponding Wilson 95\% CIs were estimated for each infection (by Cryptosporidium spp., G. lamblia, and E. histolytica) [26]. Cross tabulations were constructed between dependent (the three mentioned infections), and independent variables (e.g., sex, caregiver's education level, household members with a cut-off of five members). Crude and adjusted odds ratios were estimated through simple and multiple logistic regression models using as dependent variables infection by Cryptosporidium spp. and G. lamblia. Independent variables with $p$-values $\leq 0.2$ in the simple logistic regression and potential confounders were included in the multiple logistic regression models to obtain adjusted odds ratio. Hosmer and Lemeshow test was used to assess the fit of the multiple logistic regression models. Pairwise deletion procedure was used to handle missing data in the inferential analysis. $P$-value of less than 0.05 was considered statistical significant.

\section{Results}

During the analysis period, 276 children admitted at HCN were included. However, 99.3\% (274/276) of the children provided sufficient stool amounts to obtain results for Cryptosporidium spp. and G. lamblia and, 99.6\% (275/276) for E. histolytica. Overall, 98.9\% (273/ 276) of the children had enough stool amounts to obtain results for the three protozoans.

\section{Sample characteristics}

Among the included children, 55.8\% (154/276) were male; $48.6 \%(134 / 276)$ were less than 12 months of age; $46.0 \%(127 / 276)$ had caregivers with a secondary or greater educational level. Also, 64.5\% (178/276) were living in a household with more than four members (Table 1). Animal contact was reported in 46\% (127/ 276); $51.1 \%$ (141/276) drank water from the public tap, and $63.6 \%(171 / 276)$ were well-nourished for WAZ (Table 1).

\section{The overall frequency of intestinal protozoa}

Infection by any enteric protozoa was seen in 21.4\% (59/ 276; 95\% CI: 17.0-26.6) of the children. Cryptosporidium spp. was the most common protozoa at $13.9 \%(38 / 274$; 95\% CI: 10.3-18.5), followed by G. lamblia at 9.1\% (25/ 274; $95 \%$ CI: $6.3-13.1)$ and E. histolytica at $0.4 \%(1 / 275$; 95\% CI: 0.1-2.0).

Positive children for Cryptosporidium spp. and G. lamblia had a median age (in months) and interquartile interval of 15 (10-24) and 11 (8-20), respectively.

Co-infection between two protozoa was observed in $1.8 \%(5 / 273)$ of children. The most and least common co-infections were Cryptosporidium spp./G. lamblia 
Table 1 Characteristics of children hospitalized with diarrhoea in HCN, March 2015 to January 2018, Nampula, Mozambique

\begin{tabular}{|c|c|c|}
\hline Characteristics & $N=276$ & $\%$ \\
\hline \multicolumn{3}{|l|}{$\overline{\operatorname{sex}}$} \\
\hline Male & 154 & 55.8 \\
\hline Female & 122 & 44.2 \\
\hline \multicolumn{3}{|c|}{ Age categorized (in months) } \\
\hline $0-11$ & 134 & 48.6 \\
\hline $12-23$ & 93 & 33.7 \\
\hline $24-59$ & 49 & 17.8 \\
\hline \multicolumn{3}{|c|}{ Caregiver Education Level } \\
\hline Illiterate & 42 & 15.2 \\
\hline Primary & 104 & 37.7 \\
\hline Secondary/Above & 127 & 46.0 \\
\hline Unknown/Missing & 3 & 1.1 \\
\hline \multicolumn{3}{|c|}{ Number of Members in the Child Household } \\
\hline$<5$ & 76 & 27.5 \\
\hline$\geq 5$ & 178 & 64.5 \\
\hline Unknown/Missing & 22 & 8.0 \\
\hline \multicolumn{3}{|l|}{ Animal contact } \\
\hline No & 148 & 53.6 \\
\hline Yes & 127 & 46.0 \\
\hline Unknown/Missing & 1 & 0.4 \\
\hline \multicolumn{3}{|l|}{ Drinking-Water Source } \\
\hline Well & 58 & 21.0 \\
\hline Piped water & 74 & 26.8 \\
\hline Public tap & 141 & 51.1 \\
\hline Others & 2 & 0.7 \\
\hline Unknown/Missing & 1 & 0.4 \\
\hline \multicolumn{3}{|c|}{ Underweight (Weight-for-age Z-Score) } \\
\hline No & 171 & 63.6 \\
\hline Yes & 79 & 29.4 \\
\hline Unknown/Missing & 19 & 7.1 \\
\hline
\end{tabular}

1.4\% (4/273) and, Cryptosporidium spp./E. histolytica $0.4 \%(1 / 273)$, respectively.

\section{Factors related to infection by Cryptosporidium spp., Giardia Iamblia, and Entamoeba histolytica}

Children whose caregivers had primary education level were less likely to be infected by Cryptosporidium spp. (Adjusted Odds Ratio: 0.290, 95\% CI: 0.091-0.916) compared with the illiterates. Underweighted children were 2.7 times more likely of being infected by Cryptosporidium spp. compared to well-nourished children (p-value = 0.011; 95\% CI: 1.261-5.798) (Table 2).

Children living in a household with more than four members were 4.7 times more likely to be infected by $G$. lamblia compared with children from households with fewer members $(p$-value $=0.039 ; 95 \%$ CI: $1.083-20.935)$ (Table 2).

E. histolytica was detected in a single male child, 11 months old, co-infected by Cryptosporidium spp. and undernourished. Due to the low positivity, logistic regression models were not built for infection by $E$. histolytica.

\section{Discussion}

Findings from this analysis suggest that pathogenic intestinal protozoa infection is a public health problem in this setting, with one in five children with diarrhoea infected with at least one intestinal protozoa. The overall frequency of parasitic infections (21.4\%) is higher than reported in the southern region of Mozambique (14.4 and $16.1 \%)[15,16]$. Differences observed may be due to the fact we used a more sensitive technique compared to microscopy used in the previous studies [27, 28].

Cryptosporidium spp. was the most common parasite (13.9\%), followed by G. lamblia (9.7\%) and E. histolytica $(0.4 \%)$. Using the same diagnostic technique, a rural setting in the Manhiça district showed higher frequencies for Cryptosporidium spp. (18.7\%) and G. lamblia (17.2\%) among children with diarrhoea [7]. E. histolytica was observed in less than $1 \%$ of the overall samples, similar to the reported in Tanzania, a country near Nampula province [6]. However, in the Manhiça district, the frequency of $E$. histolytica/dispar was much higher, $10.2 \%$, suggesting different geographic distribution for this protozoa [7]. Specific tools for E. histolytica would better estimate of the occurrence of this parasite in the Manhiça district as the diagnostic tool used detects $E$. histolytica/dispar. The Manhiça district is a rural setting, where the children have more contact with soil, unimproved sanitary conditions including management of sewage, hygienic habits, and access to parasitic drugs [29].

E. histolytica was detected in an eleven months male child, underweighted and co-infected by Cryptosporidium spp. It is suggested that the male gender is more susceptible to infections due to androgens which reduce host immunity [30].

Less than $2 \%$ of the sample were co-infected. Previous studies conducted elsewhere in Africa also observed coinfections ranging from 0.25 to $43.4 \%$ [31-36]. It has been postulated that co-infections with G. lamblia can modulate the presence of symptoms in enteric infections. For example, co-infection between G. lamblia and rotavirus showed a fewer number of diarrhoea episodes compared to single infections by rotavirus [37]. On the other hand, previous studies indicated that G. lamblia was more common in non-diarrhoeal children [3, 7, 38], suggesting that symptoms in children infected by $G$. lamblia will be observed if there is another enteric 


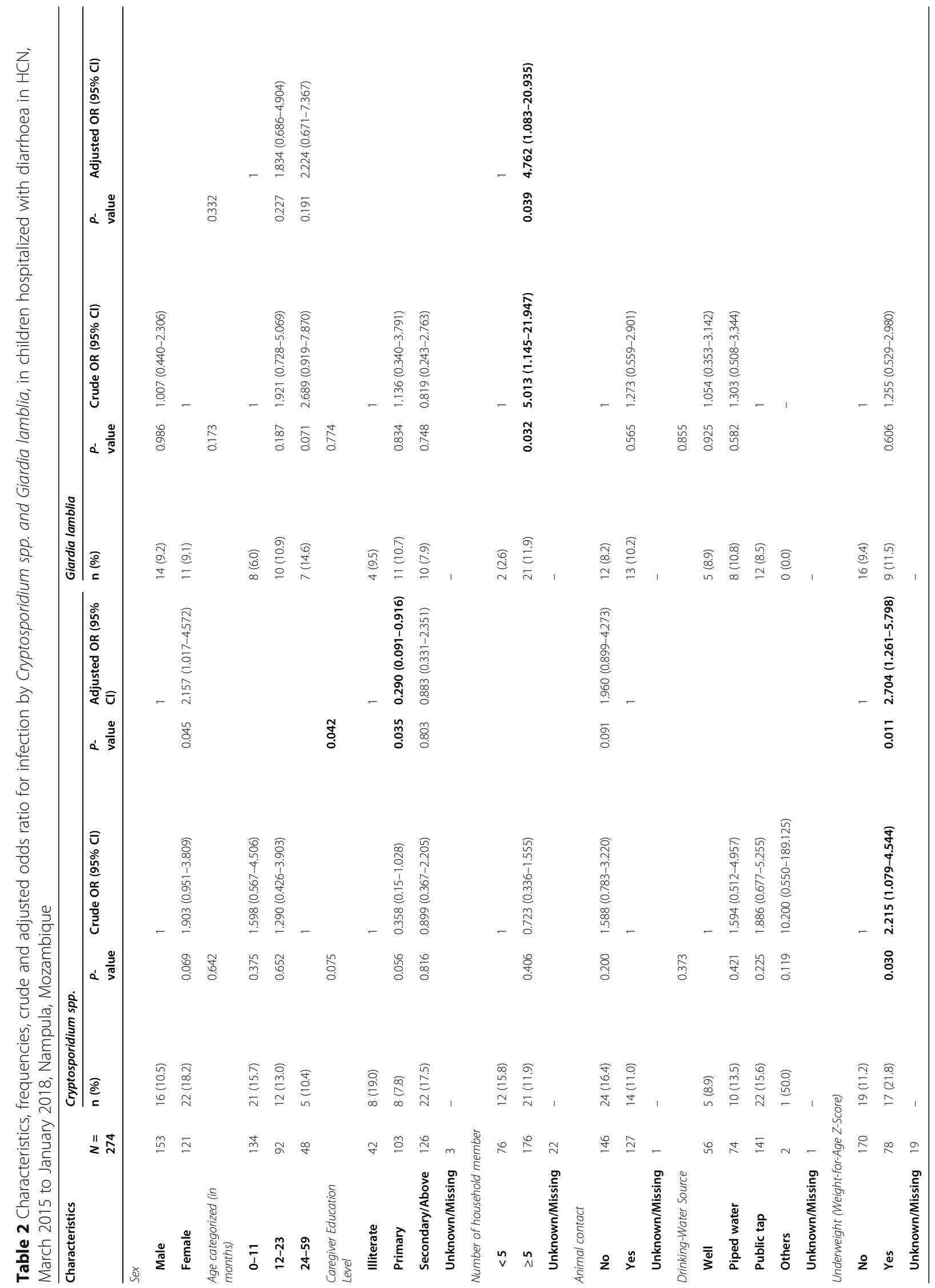


pathogen that can contribute to a clinical profile. Further analysis needs to be done to evaluate the clinical characteristic of co-infections, including the presence of $G$. lamblia.

The caregiver's education level was an independent risk factor for infection by Cryptosporidium spp. It was previously observed that a higher education level is directly associated with better hygiene habits and sanitary conditions. Therefore children with caregivers who are literate will be less susceptible to infection [10-12, 39, 40].

Undernutrition and infection by Cryptosporidium spp. share a similar geographic distribution [13]. The infection can cause inflammation and damage to the small intestine, leading to an undernourished profile and growth impairment [13]. An association between G. lamblia and nutritional status was not observed in this analysis. Although this relationship has been reported for chronic infection with G. lamblia [41]. However, we could not identify if children positive for G. lamblia had a chronic infection.

A high number of members in the children's household was a risk factor for infection by G. lamblia. Little is known regarding this outcome, especially when protozoa infective-dose is considered; however, it is known that crowded environments contribute to parasites transmission [11, 12]. On the contrary, the relation between Cryptosporidium spp. and the number of household members was not observed. G. lamblia was more common in children without diarrhoea aged 12 to 59 months than in the ones with diarrhoea in the Global Enteric Multicenter Study (GEMS), which included Gambia, Mali, Mozambique, Kenya, India, Bangladesh, and Pakistan. Therefore, it seems that G. lamblia is more ubiquitous than Cryptosporidium spp., making the probability of a child to be infected by G. lamblia in a crowded environment much greater than by Cryptosporidium spp. [3].

A previous study conducted at HCN between 2012 and 2013, included children with undernourished, HIV, and diarrhoea, observed G. lamblia genotype B as the most common, which is related to anthroponomical transmission [18]. Previous results from HCN suggests that the absence of relation between animal contact and infection by G. lamblia in our sample may indicate the circulation of an anthroponomical genotype [18].

The drinking water source has been suggested as one of the routes for transmission of intestinal protozoa [14, $42,43]$. Transmission by water sources has been pointed mostly in developed countries outside Africa. Detection and notification are mostly reported by water suppliers in the outbreak context [9]. No outbreak was recorded during the survey period in the $\mathrm{HCN}$, which can justify the absence of a relationship between drinking water source and infection by an intestinal protozoa.
The limitations in this analysis were: collection of a single stool sample from each participant, although it is recommended testing three samples for each individual, to avoid underestimation; and using a cross-sectional study design, which cannot measure causality between dependent and independent variables [44, 45]. However, we used a more sensitive diagnostic technique to minimize the underestimation of the true occurrence of intestinal protozoa in our samples [27, 28].

Our data indicate the presence of intestinal protozoa in $21.4 \%$ of the children with diarrhoea in HCN, however, $78.6 \%$ of the hospitalized children have unknown aetiology. Novel diagnostic tools such as multiplex techniques that identify a wider range of enteric pathogens should be considered to estimate the true burden of enteric pathogens in children with diarrhoea as well as co-infections and their clinical profiles especially in the presence of $G$. lamblia [4, 37].

\section{Conclusions}

Cryptosporidium spp. and Giardia lamblia were the most common pathogenic intestinal protozoa detected in children with diarrhoea hospitalized in the Hospital Central de Nampula. The results obtained highlight the importance of further exploring the caregiver's education level, children's nutritional status for infections with Cryptosporidium spp., and living conditions, namely crowded households for infections with G. lamblia in children younger than five years.

\section{Abbreviations}

AOR: Adjusted odds ratio; Cl: Confidence interval; DFG: Deutsche Forschungsgemeinschaft; EFINTD: European Foundation Initiate into African Research in Neglected Tropical Diseases; Gavi-HSS: The Vaccine Alliance Health System Strengthening; GEMS: Global Enteric Multicenter Study; ELISA: Enzyme-Linked Immunosorbent Assay; IBM SPSS: International Business Machines Corporation Statistical Package for the Social Science; INS: Instituto Nacional de Saúde; HCN: Hospital Central de Nampula; HIV: Human Immunodeficiency Virus; ViNaDia: Vigilância Nacional de Diarreias; WAZ: Weight-for-Age Z-score; WHO: World Health Organization

\section{Acknowledgments}

We want to thank the caretakers who consented for their children to be enrolled in the surveillance. For their contribution in the ViNaDia procedures, we would like to thank Herminio Cossa, Juma Cantoria, Osvaldo Laurindo, Angelina Pereira, Mulaja Kabeya Étienne, Celso Gabriel, Titos Maulate, Julieta Ernesto, Saide Artur, Musangu Mukinayi, Francisca Ricardo, Siasa Mendes, Marcelino Tsowo, Direcção Clínica de Pediatria do Hospital Central de Nampula, Carlos Guilamba, Celina Nhamuave and Miguel Bambo.

\section{Authors' contributions}

ILCC-M, ELAMG, EMA, JJC, MC, JSL, JAMS, LVM-C, DMB, NdD: Involved in the ViNaDia design. AFLB, ILCC-M, EMA, JJC, MC, AC: Data collection and validation. AFLB, ILCC-M, SDAM, ELAMG, BAM, EMA: Laboratory procedures. AFLB, TAK, LAPG: Data analysis. NdD: Funding acquisition. AFLB: Writing original draft. All authors have been involved in drafting, read, and approval of the final manuscript.

\section{Funding}

The National Surveillance of Diarrhoea was supported by a Senior Fellowship awarded to Nilsa de Deus by the European Foundation Initiate for African 
Research into Neglected Tropical Diseases (EFINTD, grant number 98539), World Health Organization (WHO), Deutsche Forschungsgemeinschaft (DFG, grant number JO369/5-1) - where Adilson Fernando Loforte Bauhofer, Benilde António Munlela, and Assucênio Chissaque are fellows - and The Vaccine Alliance (Gavi) through Health System Strengthening project. The funders had no role in the ViNaDia and in the present analysis design, data collection, decision to publish, or preparation of the manuscript.

\section{Availability of data and materials}

The dataset used and/or analysed during the current analysis are available from the corresponding author on reasonable request.

\section{Ethics approval and consent to participate}

The ViNaDia protocol was approved by the Mozambique National Committee for Bioethics in Mozambique (IRB00002657, reference Nr. 348/ CNBS/13). Written informed consent was obtained from caregivers, after explaining the ViNaDia aims and procedures. Data confidentiality was ensured by storing the physical data collection and consent forms in a lockable cabinet with access only to the ViNaDia investigators.

\section{Consent for publication}

Not applicable.

\section{Competing interests}

The authors have declared that no competing interests exist.

\section{Author details}

IInstituto Nacional de Saúde (INS), Maputo, Mozambique. ${ }^{2}$ Instituto de Higiene e Medicina Tropical, Universidade Nova de Lisboa, Lisboa, Portugal. ${ }^{3}$ Institute of Tropical Medicine, Antwerp, Belgium. ${ }^{4}$ Centro de Biotecnologia, Universidade Eduardo Mondlane, Maputo, Mozambique. Institute for Global Health Sciences, University of California San Francisco, California, USA. ${ }^{6} \mathrm{Global}$ Health and Tropical Medicine, Instituto de Higiene e Medicina Tropical, Universidade Nova de Lisboa, Portugal and Centro de Estatística e Aplicações da Universidade de Lisboa, Lisboa, Portugal. 'Departamento de Ciências Biológicas, Universidade Eduardo Mondlane, Maputo, Mozambique.

Received: 20 May 2020 Accepted: 9 February 2021

Published online: 23 February 2021

\section{References}

1. Fischer Walker CL, Aryee MJ, Boschi-Pinto C, Black RE. Estimating Diarrhea Mortality among Young Children in Low and Middle Income Countries. Myer L, editor. PLoS ONE. 2012;7(1):e29151.

2. Guerrant RL, Hughes JM, Lima NL, Crane J. Diarrhea in Developed and Developing Countries: Magnitude, Special Settings, and Etiologies. Clin Infect Dis. 1990:12(Supplement 1):S41-50.

3. Kotloff KL, Nataro JP, Blackwelder WC, Nasrin D, Farag TH, Panchalingam S, Wu Y, Sow SO, Sur D, Breiman RF, Faruque AS, Zaidi AK, Saha D, Alonso PL, Tamboura B, Sanogo D, Onwuchekwa U, Manna B, Ramamurthy T, Kanungo S, Ochieng JB, Omore R, Oundo JO, Hossain A, Das SK, Ahmed S, Qureshi S, Quadri F, Adegbola RA, Antonio M, Hossain MJ, Akinsola A, Mandomando I, Nhampossa T, Acácio S, Biswas K, O'Reilly CE, Mintz ED, Berkeley LY, Muhsen K, Sommerfelt H, Robins-Browne RM, Levine MM. Burden and aetiology of diarrhoeal disease in infants and young children in developing countries (the Global Enteric Multicenter Study, GEMS): a prospective, case-control study. Lancet. 2013;382(9888):209-22.

4. Liu J, Platts-Mills JA, Juma J, Kabir F, Nkeze J, Okoi C, Operario DJ, Uddin J, Ahmed S, Alonso PL, Antonio M, Becker SM, Blackwelder WC, Breiman RF, ASG F, Fields B, Gratz J, Haque R, Hossain A, Hossain MJ, Jarju S, Qamar F, Iqbal NT, Kwambana B, Mandomando I, TL MM, Ochieng C, Ochieng JB, Ochieng M, Onyango C, Panchalingam S, Kalam A, Aziz F, Qureshi S, Ramamurthy T, Roberts JH, Saha D, Sow SO, Stroup SE, Sur D, Tamboura B, Taniuchi M, Tennant SM, Toema D, Wu Y, Zaidi A, Nataro JP, Kotloff KL, Levine MM, Houpt ER. Use of quantitative molecular diagnostic methods to identify causes of diarrhoea in children: a reanalysis of the GEMS casecontrol study. Lancet. 2016;388(10051):1291-301.

5. Bauhofer AFL, Cossa-Moiane I, Marques S, Guimarães EL, Munlela B, Anapakala E, Chilaúle JJ, Cassocera M, Langa JS, Chissaque A, Sambo J, ManhiqueCoutinho L, Bero DM, Kellogg TA, de Deus N. Intestinal protozoan infections among children 0-168 months with diarrhea in Mozambique: June 2014January 2018. Taylan Ozkan A, editor. PLoS Negl Trop Dis. 2020;14(4):e0008195.

6. Tellevik MG, Moyo SJ, Blomberg B, Hjøllo T, Maselle SY, Langeland N, Hanevik K. Prevalence of Cryptosporidium parvum/hominis, Entamoeba histolytica and Giardia lamblia among Young Children with and without Diarrhea in Dar es Salaam, Tanzania. Jex AR, editor. PLoS Negl Trop Dis. 2015;9(10):e0004125.

7. Nhampossa T, Mandomando I, Acacio S, Quintó L, Vubil D, Ruiz J, Nhalungo D, Sacoor C, Nhabanga A, Nhacolo A, Aide P, Machevo S, Sigaúque B, Nhama A, Kotloff K, Farag T, Nasrin D, Bassat Q, Macete E, Levine MM, Alonso P. Diarrheal Disease in Rural Mozambique: Burden, Risk Factors and Etiology of Diarrheal Disease among Children Aged 0-59 Months Seeking Care at Health Facilities. Adam R, editor. PLoS ONE. 2015;10(5):e0119824.

8. Squire SA, Ryan U. Cryptosporidium and Giardia in Africa: current and future challenges. Parasites Vectors. 2017 Dec;10(1):195

9. Ryan U, Hijjawi N, Xiao L. Foodborne cryptosporidiosis. Int J Parasitol. 2018 Jan;48(1):1-12.

10. Nematian J, Nematian E, Gholamrezanezhad A, Asgari AA. Prevalence of intestinal parasitic infections and their relation with socio-economic factors and hygienic habits in Tehran primary school students. Acta Trop. 2004 Nov;92(3):179-86.

11. Choy SH, Al-Mekhlafi HM, Mahdy MAK, Nasr NN, Sulaiman M, Lim YAL, Surin J. Prevalence and associated risk factors of Giardia infection among indigenous communities in rural Malaysia. Sci Rep. 2015 May;4(1):6909.

12. Forson AO, Arthur I, Ayeh-Kumi PF. The role of family size, employment and education of parents in the prevalence of intestinal parasitic infections in school children in Accra. Kumar S, editor. PLoS ONE. 2018;13(2):e0192303.

13. Checkley W, White AC, Jaganath D, Arrowood MJ, Chalmers RM, Chen X-M, Fayer R, Griffiths JK, Guerrant RL, Hedstrom L, Huston CD, Kotloff KL, Kang G, Mead JR, Miller M, Petri WA, Priest JW, Roos DS, Striepen B, Thompson RCA, Ward HD, Van Voorhis WA, Xiao L, Zhu G, Houpt ER. A review of the global burden, novel diagnostics, therapeutics, and vaccine targets for Cryptosporidium. Lancet Infect Dis. 2015;15(1):85-94.

14. Xiao L. Molecular epidemiology of cryptosporidiosis: an update. Exp Parasitol. 2010 Jan;124(1):80-9.

15. Fonseca AM, Fernandes N, Ferreira FS, Gomes J, Centeno-Lima S. Intestinal parasites in children hospitalized at the central Hospital in Maputo, Mozambique. J Infect Dev Ctries. 2014;8(06):786-9.

16. Mandomando IM, Alonso PL, Macete EV, Gascon J, Ruiz J, Sacarlal J, Sanz S, Navia MM, Abacassamo F, Vila J, Vallès X. Etiology of diarrhea in children younger than 5 years of age admitted in a rural hospital of southern Mozambique. Am J Trop Med Hygiene. 2007 Mar 1;76(3):522-7.

17. Augusto G, Nalá R, Casmo V, Sabonete A, Mapaco L, Monteiro J. Geographic distribution and prevalence of schistosomiasis and soil-transmitted helminths among schoolchildren in Mozambique. Am J Trop Med Hygiene. 2009;81(5):799-803.

18. Ferreira FS. Estudo do perfil epidemiológico molecular de Giardia duodenalis em crianças dos 0 aos 59 meses de idade no Hospital Central de Nampula e sua associação com o estado nutricional, diarreia e VIH. [Portugal]: Universidade Nova de Lisboa; 2017.

19. Chissaque A, de Deus N, Vubil D, Mandomando I. The epidemiology of diarrhea in children under 5 years of age in Mozambique. Curr Trop Med Rep. 2018 Sep;5(3):115-24.

20. Diarrhoeal disease [Internet]. [cited 2020 Apr 20]. Available from: https:// www.who.int/news-room/fact-sheets/detail/diarrhoeal-disease

21. WHO | Standard deviation of anthropometric Z-scores as a data quality assessment tool using the 2006 WHO growth standards: a cross country analysis [Internet]. [cited 2020 Apr 20]. Available from: https:/www.who.int/ bulletin/volumes/85/6/06-034421/en/\#R5

22. OpenEpi - Toolkit Shell for Developing New Applications [Internet]. [cited 2020 Apr 20]. Available from: https://www.openepi.com/SampleSize/ SSPropor.htm

23. A second generation monoclonal antibody-based ELISA for detecting Cryptosporidium oocyst antigen in fecal specimens. [Internet]. [cited 2020 Apr 20]. Available from: https://www.techlab.com/diagnostics/parasitologydiagnostics/cryptosporidium-ii-pt5014/

24. GIARDIA II [Internet]. [cited 2020 Apr 20]. Available from: https://www.techla b.com/diagnostics/parasitology-diagnostics/giardia-and-cryptosporidium/gia rdia-ii/

25. A second generation monoclonal antibody-based ELISA for detecting Entamoeba histolytica adhesin in fecal specimens. [Internet]. [cited 2020 Apr 
20]. Available from: https:/www.techlab.com/diagnostics/parasitology-dia gnostics/e-histolytica-ii-t5017/

26. Sergeant ESG. Epitools Epidemiological Calculators. Ausvet [nternet]. 2018 [cited 2020 Apr 20]. Available from: https:/epitools.ausvet.com.au/summarisehome

27. Cacciò SM, Pozio E. Advances in the epidemiology, diagnosis and treatment of cryptosporidiosis. Expert Rev Anti-Infect Ther. 2006;4(3):429-43.

28. Shalash IRA, Zalat R, El-Enain G, EL-Mohandes M, EL-Faramawy M, Aly E. Comparison between modified acid fast staining and antigen detection assay as diagnostic techniques for Cryptosporidium parvum. World J Med Sci. 2016;13(1):72-8.

29. Ministério da Saúde (MISAU), Instituto Nacional de Estatística (INE), ICF International (ICFI). Moçambique Inquérito Demográfico e de Saúde 2011. Calverton: MISAU, INE e ICFI; 2011. p. 412.

30. Klein SL. The effects of hormones on sex differences in infection: from genes to behavior. Neurosci Biobehav Rev. 2000 Aug;24(6):627-38.

31. Abdel-Messih IA, Wierzba TF, Abu-Elyazeed R, Ibrahim AF, Ahmed SF, Kamal K, Sanders J, Frenck R. Diarrhea associated with Cryptosporidium parvum among young children of the Nile River Delta in Egypt. J Trop Pediatr. 2005 Jun 1;51(3):154-9.

32. Gatei W, Wamae CN, Mbae C, Waruru A, Mulinge E, Waithera T, Gatika SM, Kamwati SK, Revathi G, Hart CA. Cryptosporidiosis: prevalence, genotype analysis, and symptoms associated with infections in children in Kenya. Am J Trop Med Hyg. 2006;75(1):78-82.

33. Nazeer JT, El Sayed KK, von Thien H, El-Sibaei MM, Abdel-Hamid MY, Tawfik RAS, Tannich E. Use of multiplex real-time PCR for detection of common diarrhea causing protozoan parasites in Egypt. Parasitol Res. 2013;112(2): 595-601.

34. Banisch DM, El-Badry A, Klinnert JV, Ignatius R, El-Dib N. Simultaneous detection of Entamoeba histolytica/dispar, Giardia duodenalis and cryptosporidia by immunochromatographic assay in stool samples from patients living in the greater Cairo region, Egypt. World J Microbiol Biotechnol. 2015;31(8):1251-8.

35. Krumkamp R, Sarpong N, Schwarz NG, Adelkofer J, Loag W, Eibach D, Hagen RM, Adu-Sarkodie Y, Tannich E, May J. Gastrointestinal Infections and Diarrheal Disease in Ghanaian Infants and Children: An Outpatient CaseControl Study. Bhutta ZA, editor. PLoS Negl Trop Dis. 2015;9(3):e0003568.

36. Wasike WE, Kutima HL, Muya SM, Wamachi A. Epidemiology of Cryptosporidium spp and other enteric parasites in children up to five years of age in Bungoma County, Kenya. J Biol Food Sci Res. 2015;4(1):1-6.

37. Bilenko N, Levy A, Dagan R. J. Deckelbaum R, El-on Y, Fraser D. does coinfection with Giardia lamblia modulate the clinical characteristics of enteric infections in young children? Eur J Epidemiol. 2003;19(9):877-83.

38. Muhsen K, Levine MM. A Systematic Review and meta-analysis of the association between Giardia lamblia and endemic pediatric diarrhea in developing countries. Clin Infect Dis. 2012;55(suppl_4):S271-93.

39. Naz A, Nawaz Z, Rasool MH, Zahoor MA. Cross-sectional epidemiological investigations of Giardia lamblia in children in Pakistan. Sao Paulo Med J. 2018;136(5):449-53.

40. Júlio C, Vilares A, Oleastro M, Ferreira I, Gomes S, Monteiro L, Nunes B, Tenreiro R, Ângelo H. Prevalence and risk factors for Giardia duodenalis infection among children: a case study in Portugal. Parasites Vectors. 2012 Dec;5(1):22.

41. Thomas $\sqcup$ IV, Zweig AP, Tosh AK. An adolescent with chronic giardiasis mimicking anorexia nervosa. Int J Adolesc Med Health. 2014 May 1;26(2): 293-5.

42. Thompson RCA. The zoonotic significance and molecular epidemiology of Giardia and giardiasis. Vet Parasitol. 2004 Dec;126(1-2):15-35.

43. Burnet J-B, Penny C, Ogorzaly L, Cauchie H-M. Spatial and temporal distribution of Cryptosporidium and Giardia in a drinking water resource: implications for monitoring and risk assessment. Sci Total Environ. 2014 Feb; 472:1023-35.

44. Kesmodel US. Cross-sectional studies - what are they good for? Acta Obstet Gynecol Scand. 2018 Apr;97(4):388-93.

45. Thiese MS. Observational and interventional study design types; an overview. Biochem Med. 2014;24(2):199-210

\section{Publisher's Note}

Springer Nature remains neutral with regard to jurisdictional claims in published maps and institutional affiliations.

\section{Ready to submit your research? Choose BMC and benefit from:}

- fast, convenient online submission

- thorough peer review by experienced researchers in your field

- rapid publication on acceptance

- support for research data, including large and complex data types

- gold Open Access which fosters wider collaboration and increased citations

- maximum visibility for your research: over $100 \mathrm{M}$ website views per year

At $\mathrm{BMC}$, research is always in progress.

Learn more biomedcentral.com/submissions 